\title{
Enriched cultivation of Lentinus squarrosulus (Mont.) Singer: A newly domesticated wild edible mushroom in the Philippines
}

\author{
De Leon AM ${ }^{1,2}$, Guinto LJZG ${ }^{1}$, De Ramos PDV ${ }^{1}$, Kalaw SP ${ }^{1,2}$ \\ ${ }^{1}$ Department of Biological Sciences, College of Arts and Sciences, Central Luzon State University, Science City of \\ Muñoz, Nueva Ecija, Philippines 3120 \\ ${ }^{2}$ Center for Tropical Mushroom Research and Development, Central Luzon State University, Science City of Muñoz, \\ Nueva Ecija, Philippines 3120
}

De Leon AM, Guinto LJZG, De Ramos PDV, Kalaw SP 2017 - Enriched cultivation of Lentinus squarrosulus (Mont.) Singer: A newly domesticated wild edible mushroom in the Philippines. Mycosphere 8(3), 615-629, Doi 10.5943/mycosphere/8/3/9

\begin{abstract}
Lentinus squarrosulus (Mont.) Singer is a tropical white rot macro fungus that belongs to family Polyporaceae. In order to domesticate this wild edible species, the influence of indigenous culture media, physical conditions $(\mathrm{pH}$, aeration, illumination and temperature) and grains spawn materials were evaluated. Moreover, the fruiting body performance was evaluated on enriched rice straw and sawdust based substrate formulations. The mycelia grew best on potato sucrose gelatin with a $\mathrm{pH}$ of 6.5-7.0 cultured in sealed plates incubated in alternating light and dark condition at room temperature (32 C). Both Sorghum bicolor grain and crack Zea mays grain produced a very luxuriant mycelial growth with the shortest incubation period of 6 days at $31.5 \mathrm{C} \pm 0.55$. The recorded incubation period for the fruiting spawn took 16 days to fully ramify the substrate. The highest number of fruiting bodies $(9.33 \pm 1.35),(18.33 \pm 6.62)$, mean weight $(90 \mathrm{~g} \pm 16.67),(90 \mathrm{~g}$ $\pm 29.06)$ and biological efficiency $(18 \%)$ were obtained in substrates supplemented with $15 \%$ rice bran and $20 \%$ rice hull respectively. The substrate supplemented with $5 \%$ rice hull registered the longest length and widest diameter of stipe with means of $43.01 \mathrm{~mm} \pm 5.09$ and $7.24 \mathrm{~mm} \pm 0.75$ correspondingly. The largest pileus $(71.92 \mathrm{~mm} \pm 2.69)$ was recorded in substrate with $20 \%$ rice hull. However no significant differences among the different treatments were noted.
\end{abstract}

Key words - basidiocarp - biological efficiency - enriched cultivation - optimum condition

\section{Introduction}

Mushrooms are natural recycler of agricultural wastes because they can convert lignocellulosic materials into protein rich healthy food (FAO 2002). Their flavor, texture and nutritional value provide an excellent food source (Mata et al. 2005). In the Philippines, edible mushrooms particularly paddy straw mushroom (Vovariella volvacea) and oyster mushroom (Pleurotus spp.) are now cultivated commercially in different parts of the country (Reyes et al. 2009b). However, aside from these mushroom species, there are a number of wild edible mushrooms which can be cultivated because of their potential use in the culinary and nutraceutical industry (Sunagawa and Magae 2005, Mata et al. 2005). 
Lentinus squarrosulus is a wild edible mushroom which is commonly found growing in the wild on decaying logs of trees during rainy season. Similar to other species of macrofungi, this mushroom can grow on a wide variety of substrates and habitats. Many species of Lentinus have been reported to grow in nature on special substrates and can be grown on pasteurized substrates (Morais et al. 2000, Philippousis et al. 2001). Recently, L. squarrosulus was found growing in Zambales, Philippines (De Leon et al. 2013c). This mushroom species has not been cultivated on a large scale for the production of fruiting bodies (Mhd Omar et al. 2011). The tough fruiting body of this mushroom is rich in proteins, sugars, lipid, amino acids, vitamin B, C, and D, and minerals (Royse et al. 1990). It has been reported that liquid fermentation of mushrooms in general, produces large amounts of uniform mycelial biomass as a source of bioactive compounds (Mhd Omar et al. 2011).

The tropical climate of the Philippines favors the growth of many wild species of macrofungi, e.g. Schizophyllum commune Fr. (Bulseco et al., 2005), Coprinus comatus (O.F.Mull.:Fr) Pers. (Reyes et al. 2009b), Collybia reinakeana P. Henn. (Reyes et al. 1997), Lentinus sajor-caju Fr. (Cuevas et al. 2009), Lentinus tigrinus (Bull) Fr. (Dulay et al. 2012a), including L. squarrosulus (De Leon et al. 2013b). Moreover, there are many agricultural and industrial wastes that can be used in mushroom cultivation. Also, many mushroom species have potential uses and if cultivated, these wild edible fungal species can also be used to generate livelihood among local communities to ensure food security (Reyes et al. 2009a). Although many mushroom species can be successfully cultivated through the use of rice straw and sawdust based substrate formulation developed by the Center for Tropical Mushroom Research and Development, Central Luzon State University, addition of supplements might substantially increase the yield per unit weight of this mushroom. Therefore, this study was undertaken to investigate the optimum condition for mycelial growth and fruiting body performance of $L$. squarrosulus on rice straw based substrate formulation supplemented with rice bran and rice hull.

\section{Materials \& Methods}

\section{Mushroom collection}

Pure culture of Lentinus squarrosulus strain ZB12MF02 was obtained from the culture collection of the Center for Tropical Mushroom Research and Development (CTMRD), Department of Biological Sciences, College of Art and Sciences, Central Luzon State University. This culture was collected from the Aeta communities in Zambales and optimized by De Leon et al. $(2012,2013 b, c)$. The strain was inoculated into the potato dextrose agar (PDA) plates. The culture was covered with parafilm then it was incubated at $27 \mathrm{C}$ until the plates are fully ramified with the mycelia.

\section{Study I. Nutritional Requirements for the mycelial growth of Lentinus squarrosulus}

The mycelial growth performance was evaluated using different indigenous culture media: potato sucrose gelatin (PSG), rice bran decoction gelatin (RBDG), crack corn decoction gelatin (CCDG), and coconut water gelatin (CWG). In the preparation of PSG, RBDG and CCDG, one liter in separate decoctions of potato, rice bran, yellow corn grits, were added with $20 \mathrm{~g}$ each of shredded white gelatin bars and $10 \mathrm{~g}$ of sucrose. To prepare CWG, one liter of coconut water was filtered using cheese cloth, boiled and added with $20 \mathrm{~g}$ of shredded gelatin. The newly prepared indigenous culture media were sterilized at $121 \mathrm{C}$ or 15 pounds per inch (psi) for 15 minutes. After sterilization decoctions were pour plated in sterile petri plates. Then, from the revived culture, 10 $\mathrm{mm}$ diameter mycelial disc was inoculated centrally on the prepared indigenous culture media. The inoculated plates were incubated at room temperature $31.5 \mathrm{C} \pm 0.55$.

\section{Study II. Physical Requirements of Mycelial Growth pH Level}

The most appropriate culture medium that was obtained in study I, were adjusted to different $\mathrm{pH}$ levels: 5.0, 5.5, 6.0, 6.5, 7.0, 7.5 and 8.0 using $0.1 \mathrm{M} \mathrm{NaOH}$ and $0.1 \mathrm{M} \mathrm{HCl}$. The 
culture medium with different $\mathrm{pH}$ levels was aseptically inoculated with approximately $10 \mathrm{~mm}$ fungal disc to allow the ramification of mycelia.

\section{Aeration}

The lid of the Petri plates inoculated with Lentinus squarrosulus were sealed with parafilm to prevent entrance of air into the petri plates and the other group of inoculated petri plates was not sealed. The plates were incubated at room temperature to allow the full ramification of the mycelia.

\section{Illumination}

One group of the inoculated petri plates was expose to artificial light (fluorescent light) until fully ramified. The other group of inoculated petri plates was covered with carbon paper. While the last group which served as the control was the inoculated plates that are incubated in a normal light and dark condition. All treatments were incubated to allow the full ramification of mycelia.

\section{Temperature}

The inoculated plate was placed in different temperature condition such as 32, 15 and $40 \mathrm{C}$. The temperature was monitored using a thermometer. All the inoculated plates (in triplicates) were incubated to allow full ramification of its mycelia. The daily mycelial growth in diameter of $L$. squarrosulus was measured using a vernier calliper until full ramification in all the treatments of study I and II.

\section{Study III. Evaluation of Different Materials for the Mother Spawn Production for Lentinus squarrosulus}

\section{Preparation, Sterilization and inoculation}

This study evaluated the mycelial growth of L. squarrosulus on Sorghum bicolor, crack Zea mays and unmilled Oryza sativa seeds for the production of L. squarrosulus mother grain spawn.

Each grain was boiled until tender. Dried until $60 \%$ humidity was attained. The grain was dispensed in clean glass bottles. The bottled substrates were plugged with cotton and wrap with aluminum foil, then, it was sterilized at a pressure of 15 psi for 45 minutes. Once cooled, the sterilized bottled substrates were inoculated with $10 \mathrm{~mm}$ diameter mycelial disc of L. squarrosulus. This was incubated at room temperature $(32 \mathrm{C})$. The spawn which is fully ramified in the shortest period of incubation time and has thickest mycelial density was the criteria used in choosing the best mother spawning materials.

\section{Statistical analysis}

All the treatments were laid out in complete randomized design under laboratory conditions. One-way analysis of variance (ANOVA) was used to determined significant differences between treatments using least significant differences (LSD) at $5 \%$ level of significance. The SAS 9.1 program were used for the analysis.

\section{Study IV. Evaluation of fruiting body performance in enriched rice straw-sawdust based substrate formulation}

\section{Preparation of enriched substrates}

Rice straw was initially composted by soaking in a water tank for three days to ferment. Then, the tank was drained with water. The rice straw was hauled from the tank, piled and covered with sacks to stimulate the growth of natural decomposers. The rice straw was composted for one week and aerated by turning the pile with a spading fork every two days interval. Finally, the composted rice straw was chopped into small pieces, and the substrates were formulated by mixing 8 parts of the composted rice straw with 2 parts of saw dust (De Leon et al. 2013a) and enriched separately with varying amount $(5-25 \%)$ of rice bran $(\mathrm{RB})$ and rice hull $(\mathrm{RH})$. The formulated 
substrates were placed on a $6 \times 12$ inches pp bags with three replicates and 5 experimental units per replicates. A pvc neck with cotton ball was placed at the open end of the bags, covered with aluminum foil and pasteurized in a pasteurization chamber for 5 hours at 60-80 C.

\section{Inoculation of enriched substrata for mass production of Lentinus squarrosulus}

The bagged substrates were aseptically inoculated with 40 grams of the grain spawn. The inoculated bags were incubated at room temperature to allow the spread of mycelia. Bags with fruiting initials were opened at one end to allow maturation of fruiting bodies. The opened fruiting bags were watered using a mister three times a day to prevent drying of the fruiting initials. Mature fruiting bodies were harvested, the size of the pileus and stipe were measured using a vernier calliper and then weighed to determine the biological efficiency. The biological efficiency was computed using the following formula:

$$
\% \text { Biological efficiency }=\frac{\text { weight of the fresh mushroom in a fruiting bags }(\mathrm{g})}{\text { weight of the substrate per bag }(\mathrm{g})} \times 100
$$

\section{Results and Discussion \\ Study I. Nutritional requirements for the mycelial growth of Lentinus squarrosulus}

A culture medium is an enriched material which is often times derived from plant based sources that can promote and sustain the mycelial growth of the desired mushroom (Reyes et al. 2009a). Table 1 presents the mycelial diameter and mycelial density of Lentinus squarrosulus on different indigenous culture media evaluated. The largest mean mycelial diameter was observed in PSG with a mean of $92.60 \mathrm{~mm} \pm 0.31$ and very thick mycelial density (Fig. 2). On the other hand, RBDG recorded the smallest mycelial diameter with a mean of $88.25 \mathrm{~mm} \pm 0.08$ and very thick mycelial density. Statistical analysis revealed significant differences in mycelial diameter among the different indigenous culture media. The luxuriant mycelial growth observed in PSG could be due to the nutrient components of potato such as carbohydrates, proteins, fats and several minerals like calcium, potassium, phosphorus, iron and vitamins such as niacin, thiamine and riboflavin (Prokop and Albert 2008). According to Lander (1984), thiamine stimulates mycelial growth of Cercospora arachidicola in liquid culture. Moreover, Madunagu (1998), revealed that thiamine is required for good growth in mushrooms and that different vitamins produce different effects on mycelial growth within a certain concentration range. The result obtained in the present study is similar with the result of Valdez (2014), who reported the luxuriant and thick mycelial growth of $P$. djamor on PSG. However De Leon et al. (2013b) reported that the mycelial growth of both $L$. squarrosulus and $P$. grammocephalus was significantly highest in CWG with mean mycelial growth of $80 \mathrm{~mm}$ in diameter and with thick mycelial density on the 8th day of incubation. The same result was obtain by Dulay et al. (2012a) on Lentinus tigrinus wherein the mycelia grew best on coconut water gulaman (local crude agar) as solid medium.

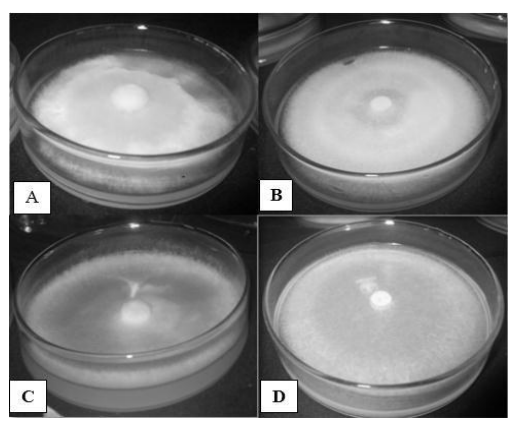

Fig. 1 - Mycelial growth of Lentinus squarrosulus on different indigenous culture media: a potato sucrose gelatin, b coconut water gelatin, c crackcorn decoction gelatin and $\mathbf{d}$ ricebran decoction gelatin after 6 days of incubation period. 
Table 1 Mycelial diameter and density of Lentinus squarrosulus on various nutritional and physical requirements for mycelial growth

\begin{tabular}{|c|c|c|}
\hline & Mycelial diameter (mm) & Mycelial density \\
\hline \multicolumn{3}{|l|}{ Culture media } \\
\hline PSG & $92.60 \pm 0.31^{\mathrm{a}}$ & ++++ \\
\hline CWG & $91.34 \pm 0.27^{\mathrm{b}}$ & ++ \\
\hline CCDG & $90.06 \pm 0.86^{\mathrm{c}}$ & + \\
\hline RBDG & $88.25 \pm 0.08^{\mathrm{d}}$ & ++++ \\
\hline \multicolumn{3}{|l|}{ pH } \\
\hline 5 & $85.07 \pm 6.33^{\mathrm{ab}}$ & +++ \\
\hline 5.5 & $84.33 \pm 6.59^{\mathrm{ab}}$ & +++ \\
\hline 6 & $81.95 \pm 8.14^{b}$ & +++ \\
\hline 6.5 & $92.04 \pm 3.26^{\mathrm{a}}$ & +++ \\
\hline 7 & $92.39 \pm 0.37^{\mathrm{a}}$ & ++++ \\
\hline 7.5 & $79.52 \pm 0.55^{\mathrm{b}}$ & +++ \\
\hline 8 & $79.45 \pm 1.40^{\mathrm{b}}$ & ++++ \\
\hline \multicolumn{3}{|l|}{ Aeration } \\
\hline Sealed & $89.19 \pm 0.70^{\mathrm{a}}$ & +++ \\
\hline Unsealed & $73.69 \pm 1.45^{\mathrm{b}}$ & + \\
\hline \multicolumn{3}{|l|}{ Illumination } \\
\hline Light & $60.49 \pm 8.41 c$ & + \\
\hline Dark & $81.18 \pm 1.69^{b}$ & ++ \\
\hline Light and Dark & $93.18 \pm 0.73^{\mathrm{a}}$ & +++ \\
\hline \multicolumn{3}{|l|}{ Temperature } \\
\hline $15 \mathrm{C}$ & $10.00 \pm 0.00^{\mathrm{b}}$ & - \\
\hline $32 \mathrm{C}$ & $92.39 \pm 0.37^{\mathrm{a}}$ & +++ \\
\hline $40 \mathrm{C}$ & $10.35 \pm 0.20^{\mathrm{b}}$ & - \\
\hline
\end{tabular}

Values are means \pm SD. Means with the same superscript in a column are not significantly different at $5 \%$ level of significance using LSD. Note: Mycelial density were evaluated as $(+)$ very thin, $(++)$ thin, $(+++)$ thick, $(++++)$ very thick and (-) no growth

\section{Study II. Physical requirements for the mycelial growth of Lentinus squarrosulus}

pH levels

Maximizing of growth rate and biomass yield and minimizing the duration of lag phase for growth of mushroom are influenced by $\mathrm{pH}$ of the media as well as inoculum size and nutrient composition (Chang and Miles 2004). The mycelial growth response of L. squarrosulus is presented in Table 1. Among the different $\mathrm{pH}$ levels evaluated, $\mathrm{pH} 7.0$ recorded the shortest mycelia colonization with the mean of $92.39 \mathrm{~mm} \pm 0.37$ however this result is statistically comparable to $\mathrm{pH} 6.5, \mathrm{pH} 5.0$ and $\mathrm{pH}$ 5.5. On the other hand, $\mathrm{pH} 8.0$ and $\mathrm{pH} 7.5$ registered the longest incubation period which is statistically comparable to $\mathrm{pH} 6.0, \mathrm{pH} 5.0$ and $\mathrm{pH}$ 5.5. Luxuriant and very thick growth of mycelia was observed in $\mathrm{pH} 7.0$ and 8.0. This result is comparable to the result of Akinyele and Adetuyi (2005) and Dulay et al. (2012a) who found that the maximum mycelia yield was observed between $\mathrm{pH} 5.5$ to 8.5 as well as and 6 to 8 in $V$. volvacea and $L$. tigrinus respectively. Also, presented by Dulay et al. (2012b) in the basidiocarp production of $L$. tigrinus that $\mathrm{pH}$ of $7.5 \mathrm{had}$ the highest percentage germination with means of $82 \%$ and $88.67 \%$ after 7 hours and 10 hours, incubation respectively. On the other hand, Osman et al. (2009) reported that 
the two strains of Lentinus edodes grow over a wide range of $\mathrm{pH}$ value, but an initial $\mathrm{pH} 7.0$ favored the highest growth and the highest extract production. While the highest mycelia dry weight was recorded at $\mathrm{pH}$ 7.0. Jonathan and Fasidi (2003) reported appreciable growth of Psathyrella atroumbonata at $\mathrm{pH} 6.5$ which is comparable to the observations of Anyakuorah et al. (1998) on the cultivation of L. squarrosulus. According to Jacob et al. (2014) the luxuriant and thickest mycelia growth was recorded in $\mathrm{pH} 8.0$ for the three strains of Pleurotus. Most common fungi grow well over the range $\mathrm{pH} 3$ to 7, although some can grow at $\mathrm{pH} 2$ and below (Smith et al., 2001). Adequate $\mathrm{pH}$ and moisture content is essential to ensure good aeration and fast mycelial growth. Van Aarle et al. (2002) reported that the low growth of mycelium at lower $\mathrm{pH}$ is caused by an aversion on the substrate. While Reyes et al. (2009b) stated that the mycelium growth of $C$. comatus was cottony and suitable in $\mathrm{pH} 6.0$ and 7.0.

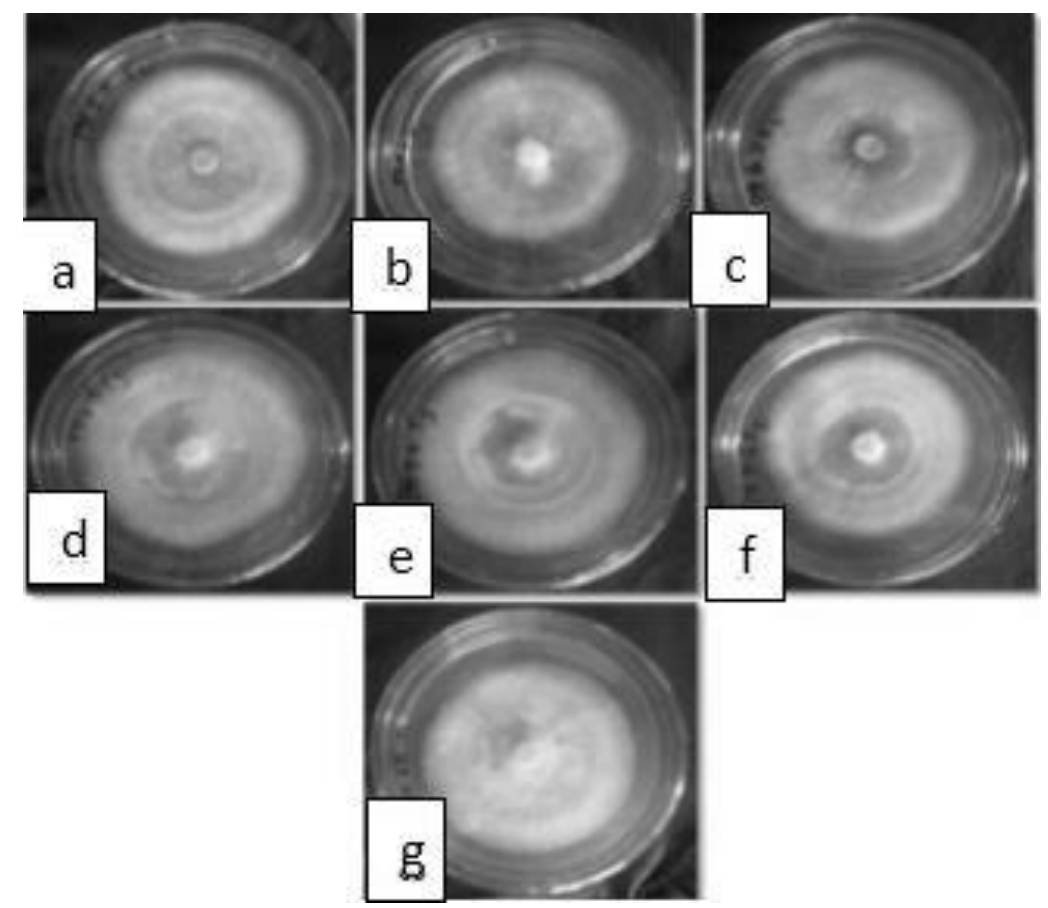

Fig. 2 - Mycelial growth of Lentinus squarrosulus on different $\mathrm{pH}$ levels: a $\mathrm{pH}$ 5.0, b pH 5.5, c pH 6.0, $\mathbf{d} \mathrm{pH} 6.5$, e $\mathrm{pH} 7.0, \mathbf{f} \mathrm{pH} 7.5$ and $\mathbf{g} \mathrm{pH} 8.0$ after 6 days of incubation period

\section{Aeration}

The components of the air that are important to most fungi are oxygen and carbon dioxide. Aeration is one of the most important factors that affect production and activity of ligninolytic enzymes (Chang and Miles 2004). Lentinus squarrosulus cultured in sealed condition produced significantly larger mean diameter of $89.19 \mathrm{~mm} \pm 0.70$ with a thick mycelial density while those that grow in unsealed condition exhibited significantly smaller mycelial diameter with a mean of $73.69 \mathrm{~mm} \pm 1.45$ and very thin mycelial density after six days of incubation. The difference in the mycelial growth rate could be due to the high concentration of $\mathrm{CO}_{2}$ on the sealed plate that stimulated the growth of mycelia. In a related study, Miguel (2012) observed luxuriant and thick mycelia growth of $P$. pulmonarius in sealed condition. Kang (2004) reported that the mycelial growth $P$. ostreatus and $P$. florida is stimulated in high $\mathrm{CO}_{2}$ concentrations up to $28 \%$ and $22 \%$, respectively. Contrary to this result L. tigrinus grew luxuriantly in neither sealed or unsealed condition (Dulay et al. 2012a). 

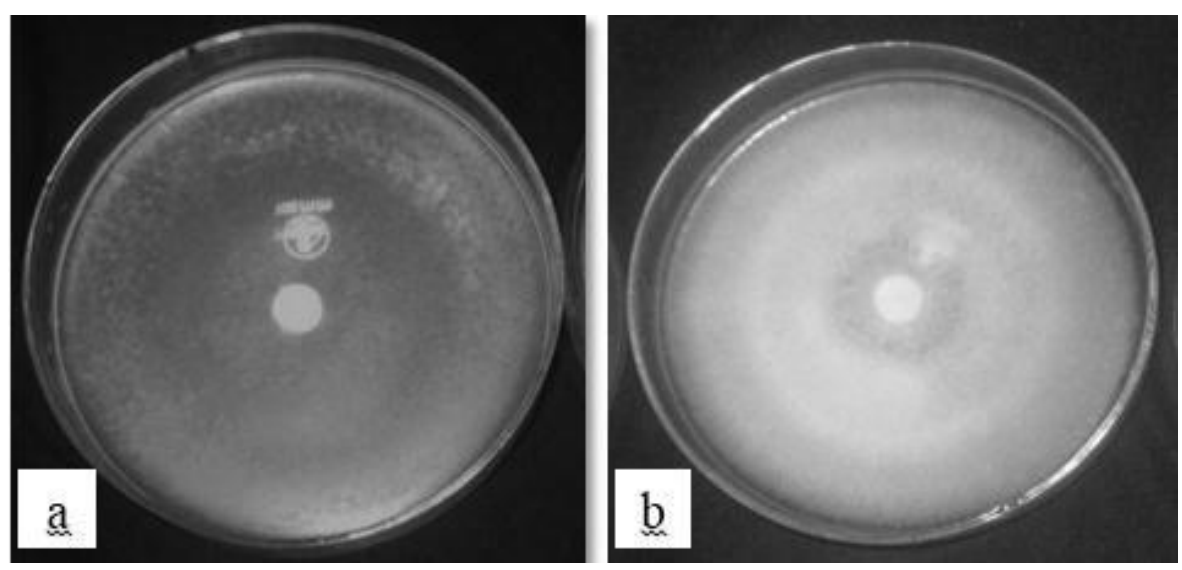

Fig. 3 - Mycelial growth of Lentinus squarrosulus on different aeration: a unsealed and b sealed after 6 days of incubation period

\section{Illumination}

Most cultivated fungi are exposed to alternating periods of daylight and darkness (Chang and Miles 2004). The influence of light conditions on mycelial growth of Lentinus squarrosulus is shown in Table 1. Among the three light conditions, cultures exposed to alternating light and dark condition significantly recorded the largest mycelial diameter with a mean of $93.18 \mathrm{~mm} \pm 0.73$ and thick mycelial density while those exposed to lighted condition registered significantly smallest mycelial growth with a mean of $60.49 \mathrm{~mm} \pm 8.41$ and very thin mycelial growth after 6 days of incubation. Chang and Miles (2004) reported that the growth of most fungi is not sensitive to light, although strong light may inhibit or even kill the organism (possibly a temperature effect). Positive response to darkness of this mushroom is comparable to the other basidiomycetes like $V$. volvacea (Reyes et al. 1998), C. comatus (Lopez et al. 2009), Agaricus blazei (Galamgam et al. 2009) and Lentinus tigrinus (Dulay et al. 2012a). However, this results contradicts the repot of Dulay et al. (2012b) on basidiospore germination of Lentinus tigrinus, wherein incubation in lighted condition (30 footcandles) significantly obtained higher percentage germination with means of $79 \%$ and $88 \%$ after 7 hours and 10 hours, respectively. Variation on the responses in illumination suggests that different basidiomycetes have varying response to light (Dulay 2011).
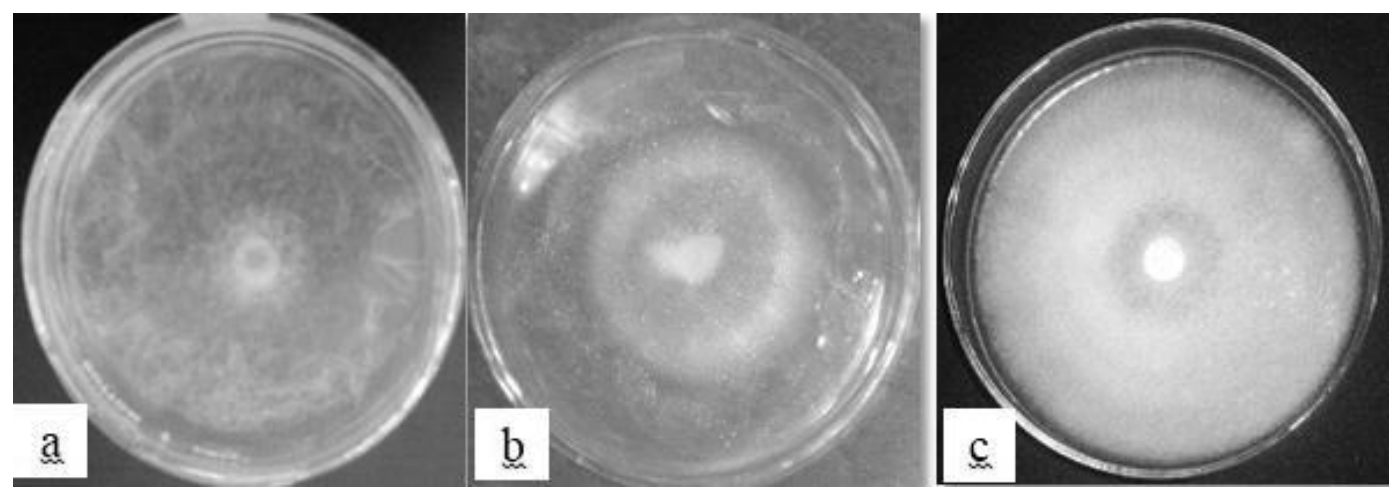

Fig.4 - Mycelial growth of Lentinus squarrosulus on different illumination: a Light (expose to artificial light), b Dark (cover with carbon paper) and $\mathbf{c}$ Light and dark or normal condition after 6 days of incubation period

\section{Temperature}

The temperature extremes (maximum and minimum) are of great importance in determining the survival and distribution of a fungal species in nature (Chang and Miles, 2004). Results revealed that room temperature recorded the largest mycelial growth with $92.39 \mathrm{~mm} \pm 0.37$ and thick mycelial density. While at $15 \mathrm{C}$ and $40 \mathrm{C}$ inhibited the mycelial growth of Lentinus 
squarrosulus. The result obtained in the present study is the same with the response of the tropical mushrooms like C. reinakeana (Reyes et al. 1997), S. commune (Bulseco et al. 2005), V. volvacea (Reyes et al. 1998) and Lentinus tigrinus (Dulay et al. 2012a). However it differs to the basidiospore germination of L. tigrinus presented by Dulay et al. (2012b) wherin basidiospores at $23 \mathrm{C}$ (air-conditioned with $48 \%$ relative humidity) recorded the highest percentage germination with means of $86 \%$ and $91.33 \%$, after 7 hours and 10 hours, respectively and the lowest percent basidiospore germination was observed at room temperature $(32 \mathrm{C}$ ) with means of $50 \%$ and $54 \%$ after 7 hours and 10 hours, respectively. Lin et al. (2003) reported that fungi can be classified as temperate, semi-temperate or tropical based on the optimum temperature for mycelial growth. Jayasinghe et al. (2008) disclosed that the most suitable temperature for the mycelial growth was 30 $\mathrm{C}$ but generally the optimal temperature range for the mycelia growth was found at 25-30 C.

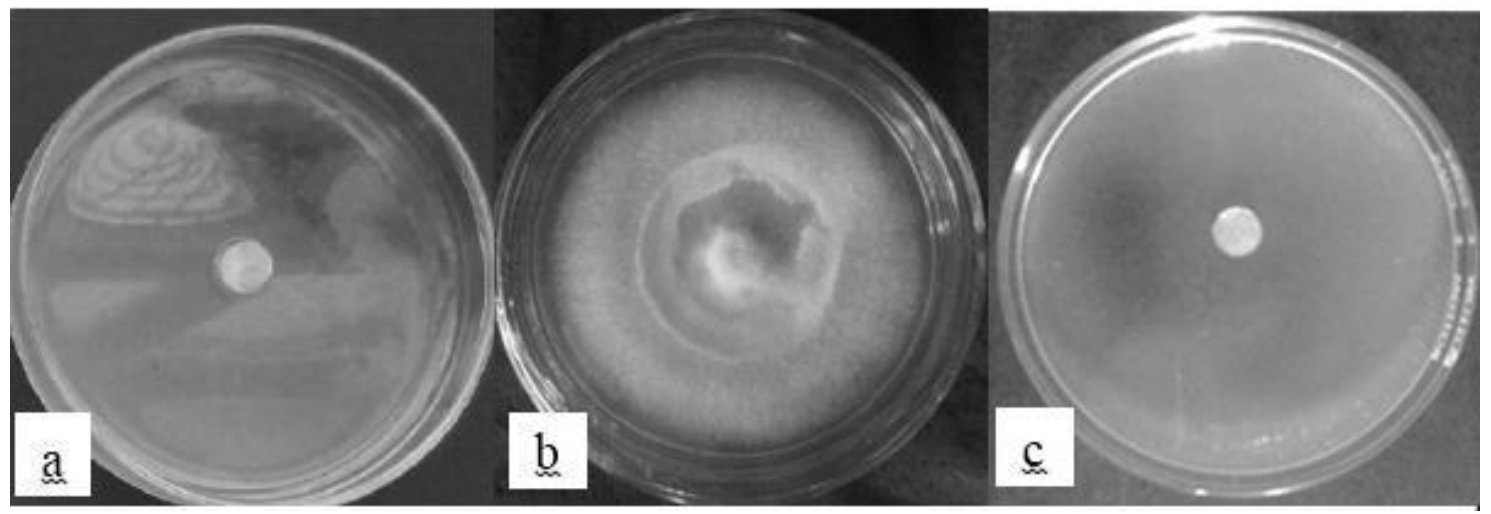

Fig. 5 - Mycelial growth of Lentinus squarrosulus on different temperature: a incubator $\left(40^{\circ} \mathrm{C}\right)$, b room temperature $\left(32^{\circ} \mathrm{C}\right)$ and $\mathbf{c}$ refrigerator $\left(15^{\circ} \mathrm{C}\right)$ after 6 days of incubation period

\section{Study III. Granulated spawning materials}

The grain spawn is the starter for the mass/bulk production of mushroom. It facilitates the rapid colonization of the mushroom substrate thus reducing the days of mycelia colonization. It is essential for mushroom production to have a good mycelia growth (Chang 2009). Sorghum bicolor and cracked Zea mays recorded the shortest incubation with a mean of 6 days, while unmilled $O$. sativa seed registered the longest period with the mean of 12 days. The efficient growth of $L$. squarrosulus on S. bicolor seeds and crack Zes mays could be attributed to their nutrient composition. According to Leder (2004), $100 \mathrm{~g}$ sorghum seeds contain $10.9 \mathrm{~g}$ protein, $3.2 \mathrm{~g}$ fat, 2.3 $\mathrm{g}$ crude fiber, $1 \mathrm{~g}$ ash, $329 \mathrm{kcal}$ of energy, $27 \mathrm{mg}$ calcium, $4.3 \mathrm{mg}$ iron, $0.3 \mathrm{mg}$ thiamin, $3.83 \mathrm{mg}$ niacin and $0.138 \mathrm{mg}$ rivoflavin. Moreover, the suitable moisture capacity of sorghum (55-60\%) contributed to mycelial proliferation (Gizaw 2010).

The result of the present study is consistent with the finding of Royse (2003), who disclosed that sorghum grains provide optimum spawn growth and quality inoculum in oyster mushroom. Also, L. squarrosulus grown in corn grits and sorghum seeds had very thick mycelial density and the shortest incubation period of 6 days (De Leon et al. 2013b). Moreover, those grain material was also found to be the best spawning material for Lentinus sajor-caju, Agaricus blazei, Auricularia polytricha and Agrocybe aegerita (Cuevas 2009, Galamgam 2009, Yabo 2011, Marcelo 2011). Futhermore, De Leon et al. (2013a) also reported that mycelial growth of L. tigrinus grown in the three spawning medium did not vary considerably. All were fully ramified at 7 days of incubation and had very thick mycelial density. This result was not consistent with the data reported by Dulay et al. (2012a) on similar spawning materials. In their study, L. tigrinus mushroom grew better on unmilled rice seeds (with 5 days incubation period) than corn grits and sorghum seeds (with a mean of 6.7 days incubation period). Cuevas et al. (2009) also reported that the spawning of mycelia of $L$. sajor-caju was superior in sorghum seeds compared with unmilled rice. For the enrichment type, corn grits provided the fastest period of primordial initiation for C. comatus and P. sajor-caju, (Dulay et al. 2014). Stanley et al. (2011) also reported that $P$. pulmonarius grew well on white 
maize, followed by red sorghum seed, millet, gunica corn, yellow corn and wheat. Ramos (2004) also confirmed that the fastest incubation and thickest mycelial density of $P$. pulmonarius on corn grits. Tinoco et al. (2001) mentioned that the larger surface area and pore of substrates support more mycelium growth rate. The thin mycelia growth observed in unmilled rice seeds could be due to the protective covering of the rice grain. Dulay et al. (2012a) explained that the hull serves as the barrier that limits the penetration of the fungal mycelia needed to acquire the nutritious part of the rice. While Oghenekaro et al. (2009) used sorghum seeds as spawning material for the cultivation of L. squarrosulus in Nigeria while in Cuba, wheat kernels were used as a spawning material for the cultivation of $P$. ostreatus.

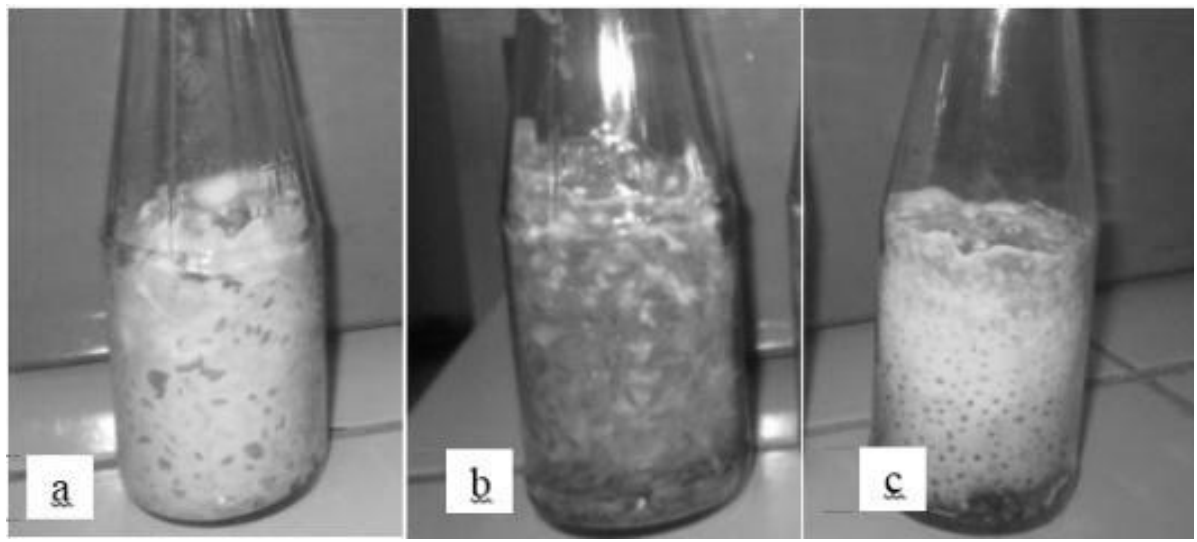

Fig. 6 - Mycelial density of L. squarrosulus on different grain spawning material: a cracked Zea mays, b unmilled Oryza sativa grains and c Sorghum bicolor after 6 days of incubation

\section{Study IV. fruiting body performance in enriched rice straw-sawdust based substrate formulation}

\section{Incubation period and Pinhead formation of L. squarrosulus}

Spawn running is the growth of mycelium into the compost, which usually lasts for two weeks (Royse et al. 1990). Substrate supplemented with 5\% and 10\% rice bran registered the shortest spawn running with a mean of 16 days (Table 2). The rest of the treatments registered a mean of 15 days to fully ramify the substrate. The one day difference in the spawn running of $L$. squarrosulus could be due to the supplementations used in the cultivation which might have affected the mycelial ramification. Okhuoya et al. (2005) in their report on the cultivation of $L$. squarrosulus on sawdust of selected tropical tree species, showed that the mushroom was able to colonize all the different substrate/supplement combinations, except the sawdust of Celtis sp., which totally failed to support the growth of the mushroom mycelium at the wheat bran supplementation of $20 \%$. Time for mycelium colonization of the substrate ranged from $7.80 \pm 0.49$ days in Celtis sp., supplemented with $1 \%$ sugar, $1 \% \mathrm{CaCO}$, and $1 \%$ sugar; to $17.50 \pm 6.50$ days in the sawdust of $C$. excelsa supplemented with $1 \% \mathrm{CaCO}, 1 \%$ sugar, and $10 \%$ wheat bran. On the other hand, Alemu (2015) reported that spawn running of L. edodes on sorghum based spawn took 25 days to colonize the substrate completely. In a study conducted by Dumale (2015) the difference in incubation period of Pleurotus florida, P. djamor and P. ostreatus is only 2 days in rice straw while 3 days in sawdust substrate, which is not very far from the result of this study. Mata et al. (2005) mentioned that factors like, temperature of the incubation room, light and humidity affect the spawn running time of mushrooms.

The formation of pinheads initially marks the start of fruiting body production. In this study, the pinhead formation of Lentinus squarrosulus on enriched RS and SD based substrate formulation is presented in Table 2. Lentinus squarrosulus grown in substrate supplemented with 5\% rice hull registered the fastest pinhead formation (1 day) while the longest period to pinhead formation was noted in $15 \%$ rice bran with a mean of 4 days. 
Table 2 Number of incubation of Lentinus squarrosulus on enriched RS and SD based substrate formulation

\begin{tabular}{lcc}
\hline Treatments & Incubation period (days) & Pinhead formation (days) \\
\hline $5 \% \mathrm{RB}$ & 16 & 2 \\
$10 \% \mathrm{RB}$ & 16 & 3 \\
$15 \% \mathrm{RB}$ & 15 & 4 \\
$20 \% \mathrm{RB}$ & 15 & 2 \\
$25 \% \mathrm{RB}$ & 15 & 3 \\
$5 \% \mathrm{RH}$ & 15 & 1 \\
$10 \% \mathrm{RH}$ & 15 & 2 \\
$15 \% \mathrm{RH}$ & 15 & 2 \\
$20 \% \mathrm{RH}$ & 15 & 3 \\
$25 \% \mathrm{RH}$ & 15 & 3 \\
\hline
\end{tabular}

The results obtained in the present study is faster than the 2.07 mean number of days to primordial formation of Pleurotus djamor cultured on rice straw and sawdust substrate (Dumale 2015) as well as the 3.29 days appearance of primordia of Pleurotus flabellatus cultured in mango sawdust (Islam et al. 2009). However Okhuoya et al. (2005) presented that the earliest time of primordial emergence in Lentinus squarrosulus was $20.60 \pm 0.16$ days (on sawdust of B. nigerica without any addition of supplements).

\section{Size of pileus and stipe size}

The diameter of pileus of Lentinus squarrosulus grown on substrate RS and SD enriched with RB and RH is presented in Table 3. L. squarrosulus cultivated in substrate supplemented with $20 \%$ rice hull registered the largest pileus diameter $(71.92 \mathrm{~mm} \pm 2.69)$ while the smallest pileus diameter was recorded in $25 \%$ rice hull supplementation with a mean of $52.82 \mathrm{~mm} \pm 7.33$. This result indicates that supplementation affects the size of the pileus of the mushroom as it produced larger pileus diameter compared to the mean pileus size $(64.79 \mathrm{~mm} \pm 18.70)$ reported by De Leon et al. (2013b) in un-supplemented cultivation. However the amount and type of the supplementation did not significantly affect the size of the pileus. Royse et al. (1990) reported that there are several sources of variations on mushroom size, which include characteristics of species of mushroom as well as their strains.

Table 3 Mean size of pileus, stipe length and stipe diameter, number, weight and percent biological efficiency of fruiting bodies of Lentinus squarrosulus on enriched RS and SD based substrate formulation

\begin{tabular}{lllllll}
\hline Treatment & Size of pileus & $\begin{array}{l}\text { Stipe } \\
\text { diameter }\end{array}$ & Stipe length & $\begin{array}{l}\text { No. of fruiting } \\
\text { bodies }\end{array}$ & $\begin{array}{l}\text { Weight of fruiting } \\
\text { bodies }\end{array}$ & $\begin{array}{l}\text { Biological } \\
\text { efficiency }\end{array}$ \\
\hline $5 \%$ RB & $55.94^{\mathrm{ab}} \pm 7.59$ & $5.62 \pm 0.93$ & $34.92 \pm 2.63$ & $5.67^{\mathrm{d}} \pm 0.19$ & $46.67^{\mathrm{d}} \pm 4.81$ & $9.33^{\mathrm{b}}$ \\
$10 \% \mathrm{RB}$ & $66.84^{\mathrm{a}} \pm 5.98$ & $6.78 \pm 1.11$ & $37.65 \pm 4.52$ & $5.00^{\mathrm{d}} \pm 0.58$ & $43.33^{\mathrm{b}} \pm 3.47$ & $8.67^{\mathrm{b}}$ \\
$15 \% \mathrm{RB}$ & $61.29^{\mathrm{ab}} \pm 10.70$ & $6.26 \pm 0.72$ & $40.98 \pm 7.87$ & $9.33^{\mathrm{bc} \pm 1.35}$ & $90.00^{\mathrm{a}} \pm 16.67$ & $18.00^{\mathrm{a}}$ \\
$20 \% \mathrm{RB}$ & $57.14^{\mathrm{ab}} \pm 19.00$ & $6.20 \pm 1.29$ & $39.75 \pm 3.08$ & $11.33^{\mathrm{b}} \pm 3.37$ & $71.67^{\mathrm{ab}} \pm 15.84$ & $14.33^{\mathrm{ab}}$ \\
$25 \% \mathrm{RB}$ & $55.26^{\mathrm{ab}} \pm 11.17$ & $6.23 \pm 0.82$ & $39.47 \pm 6.53$ & $8.00^{\mathrm{bcd} \pm 1.33}$ & $66.67^{\mathrm{ab}} \pm 15.49$ & $13.33^{\mathrm{ab}}$ \\
$5 \% \mathrm{RH}$ & $68.77^{\mathrm{ab}} \pm 6.63$ & $7.24 \pm 0.75$ & $43.01 \pm 5.09$ & $9.67^{\mathrm{bc}} \pm 2.41$ & $83.33^{\mathrm{a}} \pm 13.57$ & $16.67^{\mathrm{a}}$ \\
$10 \% \mathrm{RH}$ & $57.51^{\mathrm{ab}} \pm 11.01$ & $5.40 \pm 0.23$ & $36.27 \pm 4.30$ & $18.33^{\mathrm{a}} \pm 6.62$ & $90.00^{\mathrm{a}} \pm 29.06$ & $18.00^{\mathrm{a}}$ \\
$15 \% \mathrm{RH}$ & $62.90^{\mathrm{a}} \pm 8.90$ & $5.84 \pm 1.86$ & $34.49 \pm 7.33$ & $6.67^{\mathrm{cd}} \pm 0.51$ & $48.33^{\mathrm{b}} \pm 6.31$ & $9.67^{\mathrm{b}}$ \\
$20 \% \mathrm{RH}$ & $71.92^{\mathrm{a}} \pm 2.69$ & $6.87 \pm 1.05$ & $41.98 \pm 10.39$ & $5.67^{\mathrm{d}} \pm 0.51$ & $65.00^{\mathrm{ab}} \pm 6.67$ & $13.00^{\mathrm{ab}}$ \\
$25 \% \mathrm{RH}$ & $52.82^{\mathrm{ab}} \pm 7.33$ & $6.09 \pm 0.29$ & $34.41 \pm 5.51$ & $6.33^{\mathrm{cd} \pm 0.38}$ & $48.33^{\mathrm{b}} \pm 2.55$ & $9.67^{\mathrm{b}}$ \\
\hline
\end{tabular}

Values are means \pm SD. Means with the same superscript in a column are not significantly different at $5 \%$ level of significance using LSD. RH= Rice Hull, RB= Rice Bran 
The size of stipe of $L$. squarrosulus grown on enriched RS and SD based substrate formulation is also shown in Table 3. The largest stipe diameter and longest stipe was recorded on substrate supplemented with $5 \%$ rice hull with mean value of $7.24 \mathrm{~mm} \pm 0.75$ and $43.01 \mathrm{~mm} \pm$ 5.09, respectively. However, statistical analysis revealed no significant difference in the size of stipe among different treatments. This indicates that the amount of supplementation does not affect the size of the mushroom. However supplementation has an effect as proven by this result which is much higher than the report of De Leon et al. (2013b) in unsupplemented cultivation of $L$. squarrosulus where as the longest stipe length is only $33.08 \mathrm{~mm} \pm 3.53$ and the widest stipe diameter is $5.94 \mathrm{~mm} \pm 1.78$. On the other hand, Nwanze et al. (2005) reported that various media, oil type and rate had a highly significant effect on the stipe length and diameter as well as, pileus diameter of $L$. squarrosulus.

\section{Number of fruiting bodies and weight of fruiting bodies}

In this study, the fruiting body performance of $L$. squarrosulus on enriched RS and SD based substrate formulation is also presented in Table 3.

Results showed that substrates supplemented with $10 \%$ rice hull produced the most number of fruiting bodies (with a mean of $18.33 \pm 6.62$ ). The lowest number of fruiting bodies was observed in $10 \%$ rice bran with a mean of $5.00 \pm 0.58$. Statistical analysis showed significant difference in the number of fruiting bodies of the different treatments. The result of this study proved that supplementation could enhance mushroom production since it produced more fruiting bodies compared to the report of De Leon et al. (2013b) where L. squarrosulus produced only $14.40 \pm 12.50$ fruiting bodies in un-supplemented cultivation. The values obtained in the present study are also higher than the results obtained by Rossi et al. (2002) in L. edodes which produced a mean of 2.73-3.45 fruiting bodies with 30\% rice bran supplementation. Adesina et al. (2011) reported that cultivation of $L$. squarrosulus on bark and leaves of fruit trees supplemented with rice bran exhibited best result as supplement in the mycelial growth. Supplementation of substrates has become one of the major aspects of mushroom cultivation. This is done to increase the yield of mushroom which is in line with the finding of Zadrazil (1978) that supplements usually change the decomposition rate and the sequence of decomposition of substrate components during mushroom growth.

The weight of fruiting bodies of L. squarrosulus on enriched RS and SD substrate formulation is also presented in Table 3. The highest mean weight of fruiting bodies was observed in substrate supplemented with $10 \%$ rice hull and $15 \%$ rice bran with $90.00 \mathrm{~g} \pm 29.06$ and $90.00 \mathrm{~g} \pm$ 16.67 respectively while the lowest mean weight was recorded in $10 \%$ rice bran with mean weight of $43.33 \mathrm{~g} \pm 3.47$. However, this is comparable with substrates supplemented with $5 \%$ rice hull, $20 \%$ rice bran, $25 \%$ rice bran and $20 \%$ rice hull. The results obtained in the present study is much higher than the report of De Leon et al. (2013b) wherein un-supplemented cultivation of $L$. squarrosulus yielded only $39.14 \mathrm{~g} \pm 13.74$ total weight of fruiting bodies.

\section{Biological efficiency}

As presented in Table 3, both treatments supplemented with $15 \%$ rice bran and $10 \%$ rice hull produced the highest biological efficiency of $18 \%$, while $10 \%$ rice bran supplementation got the lowest value of $8.67 \%$ Although this result is also comparable with different supplementations (20\% rice hull, $5 \%$ rice hull, $20 \%$ rice bran and $25 \%$ rice bran). This result proved that both supplementations have the same effect that can help to improve the biological efficiency of mushrooms. This result is higher than the biological efficiency of enriched cultivation of L. tigrinus which only registered $14.66 \%$. Ayodele et al. (2007) reported a $4.27 \%$ biological efficiency of $L$. squarrosulus grown in M. altissima and Adesina et al. (2011), on the other hand, reported a $10.25 \%$ biological efficiency of $L$. squarrosulus cultivated in $S$. mombin supplemented with in rice bran. Likewise, the biological efficiency reported by Cuevas et al. (2009) of L. sajor-caju was $7.2 \%$ at 9 parts rice straw +1 part sawdust substrate formulation. However, these results except for the findings in this paper were lower compared to the biological efficiency of L. tigrinus $(15.93 \%)$ as reported by Dulay et 
al. (2012a). Perhaps, different species and even different strains of same species exhibited differences in biological efficiency.

Moonmoon et al. (2011) reported that rice bran increased productivity of mushroom due to its components such as carbohydrates, amino acids and mineral elements. On the other hand, Frimpong-manzo et al. (2011) claimed that both rice bran and rice hull contains cellulose which is important for the growth of mushroom since they are lignocellulosic.

Based on the result of this study, supplementation is important in mushroom cultivation since it can increase the biological efficiency compared to the reported $7.83 \%$ biological efficiency of un-supplemented cultivation of L. squarrosulus (De Leon et al. 2013b).

\section{Acknowledgements}

This work was dedicated to the family and friends of the authors.

\section{References}

Adesina F, Fasidi I, Adenipekun I. 2011 - Cultivation and fruit body production of Lentinus squarrosulus Mont. (Singer) on bark and leaves of fruit trees supplemented with agricultural waste. African Journal of Biotechnology 10, 4608-4611.

Akinyele BJ, Adetuyi FC. 2005 - Effect of Agrowaste pH of temperature varation on the growth of Volvariella volvaceae. Microbiology Department of Federal University of Technology. P.M.B.704, Nigeria African Journal of Biotechnology 4, 1890-1395.

Alemu F. 2015 - Cultivation of Shiitake mushroom (Lentinus edodes) on Coffee Husk at Dilla University, Ethopia. Journal of Food and Nutrition Science 3, 64-70.

Anyakuorah CI, Bayo NO, Kuboye AO. 1998 - Cultivation of Lentinus squarrosulus, an edible mushroom. Proceeding of Nigerian Society for Microbiology 1, 87-91.

Ayodele SM, Akpaja EO, Anyiador F. 2007 - Evaluation of the yield of Lentinus squarrosulus (Mont.) Singer on selected economic tree species. Pakistan J Biol Sci. 10, 4283-4286.

Bulseco MG, Abella E, Reyes R. 2005 - Morphogenesis of Schizophyllum commune, a wild edible mushroom of Mt. Nagpale, Abucay, Bataan, Philippines. J. Nature Stud 4, 20-28.

Chang ST. 2009 - Training Manual on Mushroom Cultivation Technology, United Nations-Asian and Pacific Centre for Agricultural Engineering and Machinery (UN-APCAEM), Beijing, China.

Chang ST, Miles PG. 2004 - Mushrooms, Cultivation, Nutritional Value, Medicinal Effect and Environmental Impact.CRC Press LLC. 477.

Cuevas MJ, Reyes R, Kalaw SP. 2009 - Bio physiology of Lentinus sajor-caju. J Trop Biol 7, 48.

De Leon AM, Reyes RG, Dela Cruz TEE. 2013a - Enriched cultivation of three wild strains of Lentinus tigrinus (Bull.) Fr.using agricultural wastes. Journal of Agricultural Technology 9, 1199 - 1214.

De Leon AM, Reyes RG, Dela Cruz TEE. 2013b - Lentinus squarrosulus and Polyporus grammocephalus: Newly Domesticated, Wild Edible Macrofungi from the Philippines. Philipp Agric Scientist 96, 411- 418.

De Leon AM, Reyes RG, Dela Cruz TEE. 2013c - Species Listing and Molecular Identification of Macrofungi in Six Aeta Tribal Communities in Central Luzon, Philippines. Mycosphere 4, 478-494.

De Leon AM, Reyes RG, Dela Cruz TEE. 2012 - An ethnomycological survey of macrofungi utilized by Aeta communities in Central Luzon, Philippines. Mycosphere 3, 251-259.

Dulay RMR. 2011 - Optimization of Culture Conditions, Nutritional Characterization, Toxicity and Teratogenecity of Lentinus tigrinus - A newly recorded domesticated mushroom in the Philippines. Unpublished Masteral Thesis. De La Salle University, Taft Avenue, Manila.

Dulay RM, Kalaw S, Reyes R, Cabrera E, Alfonso N. 2012a - Optimization of Culture Conditions for Mycelial Growth and Basidiocarp Production of Lentinus tigrinus (Bull) Fr., A New Record of Domesticated Wild Edible Mushroom in the Philippines. Philipp Agric Scientist 95, 209-214. 
Dulay RM, Cabrera E, Kalaw SP, Reyes RG. 2012b - Optimal growth condition for basidiospore germination and morphogenesis of Philippine wild strain of Lentinus tigrinus (Bull.) Fr. Mycosphere 3, 926-933.

Dulay RM, Arenas MC, Kalaw SP, Reyes RG, Cabrera EC. 2014 - Proximate composition and functionality of the culinary-medicinal tiger sawgill mushroom, Lentinus tigrinus (higher Basidiomycetes), from the Philippines. Int J Med Mushrooms 16, 85-94.

Dumale JV. 2015 - Growth Performance of Pleurotus species on Rice Straw and Sawdust based Substrate Formulation. Unpublished undergraduate thesis, Central Luzon State University, Science City of Munoz, Nueva Ecija, Philippines.

FAO. 2002 - FAO Rice Information. Food and Agriculture Organization of the United Nations,Rome. www.wikipedia.com/food-agriculture.

Frimpong-Manso J, Obodai M, Dzomeku M, Apertorgbor MM. 2011 - Influence of rice husk on biological efficiency and nutrient content of Pleurotus ostreatus (Jacq. ex. Fr.) Kummer. International Food Research Journal 18, 249-254.

Galamgam HD, Reyes RG, Kalaw SP. 2009 - Biophysiology of hemimatsuke (Agaricus blazei) strain 2. Journal of Tropical biology 7, 42.

Gizaw, B. 2010 - Cultivation and yield performance of Pholiota nameko on different agroindustrial wastes. Retrieved on Febraury 28, 2012. http://etd.aau.edu.et/bitstream/123456789/1435/ 3/BIRHANU\%20GIZAW.pdf

Islam MZ, Rahman MH, Hafiz F. 2009 - Cultivation of oyster mushroom (Pleurotus flabellatus) on different substrates. Int J Sustain Crop Prod 4, 45-48.

Jacob JK, Kalaw SP, Reyes RG. 2014 - MycelialGrowth Performance of Three Species of Pleurotus on Coconut Water Gulaman. Special Problem presented during the $1^{\text {st }}$ CLSUUniversity of Tsukuba. Bilateral Student Research Congress. Central Luzon State University, Science City of Munoz, Nueva Ecija.

Jayasinghe C, Imtiaj A, Hur H, Lee GW, Lee TS, Lee UY. 2008 - Favorable Culture Conditions for Mycelial Growth of Korean Wild Strains in Ganoderma lucidum. Mycobiology 36, 28 33.

Jonathan SG, Fasidi IO. 2003 - Studies on Psathyerella atroumbonata (Pegler), a Nigerian edible fungus. Food Chemistry 81, 481-484.

Kang S. 2004 - What is oyster mushroom. In, Mushroom grower's handbook 1: Oyster mushroom cultivation. Seoul, Korea: MushWorld-Heineart Inc. 53-56.

Lander KE. 1984 - Growth of Cercospora arachidicola in a glucose phosphate, asparaginethiamine agar medium. Phytopathology 54, 1236-1240.

Leder I. 2004 - Sorghum and millets in cultivated plants primarily as food sources. www.eos.net/ebooks/samples/20\%chapters/C10/E5-02-01-04.pdf.Retrievedon February 28, 2007.

Lin SB, Li CH, Lee SS, Kan LS. 2003 - Tripertene-enriched extracts of Ganoderma lucidum inhibit growth of hepatoma cells via suppressing protein kinase C and G2-phase cell cycle arrest. Life Sci 72, 2381-2390.

Lopez LLMA, Reyes RG, Kalaw SP. 2009 - Biophysiology Coprinus comatus (Muller;Fries) S. F. Gray. Journal of Tropical Biology 7, 45.

Madunagu, BE. 1998 - Collection and studies on the cultivation of Pleurotus squarrosulus (Mont) Sing. Niger. J. Sci 22, 51-55.

Marcelo VA. 2011 - Biophysiology of Agrocybe aegerita. Unpublished Undergraduate thesis. Central Luzon State University, Science City of Munoz, Nueva Ecija.

Mata G, Hernandez DM, Andreu LG. 2005 - Changes in lignocellulolytic enzyme activities in six Pleurotus spp. Strains cultivated on coffee pulp in confrontation with Trichodema spp. World Journal f Microbiology and Biotechnology 21,143-150.

Mhd Omar NA, Abdullah N, Kuppusamy UR, Abudulla MA, Sabaratnam V. 2011- Nutritional Composition, Antioxidant Activities and Antiulcer Potential of Lentinus squarrosulus (Mont) 
mycelia extract. Evidence-based Complimentary Altern Med http://dx.doi.org/10.1155/2011/539356

Miguel JT. 2012 - Optimization of Culture condition for mycelia growth of P. pulmonarius. Unpublished Undergraduate Thesis. Central Luzon State University, Science City of Munoz, Nueva Ecija.

Moonmoon M, Shelly N, Khan A, Valdin N et al. 2011 - Effects of different levels of wheat bran, rice bran and maize powder supplementation with sawdust on the production of shiitake mushroom [Lentinus edodes (Bark) Singer]. Saudi Journal of Biological Sciences 18, 323328.

Morais MH, Ramos AC, Matou N, Santous M, Oliveira EJ. 2000 - Note: production of shitake mushroom (Lentinus edodes) on lignocellulosic residues. Food Sci. Technol. Int 6, 123-128.

Nwanze PI, Khan AU, Ameh JB, Umoh VJ. 2005 - The effect of spawn grains, culture media, oil types and rates on carpophore production of Lentinus squarrosulus (Mont.) Singer. African Journal of Biotechnology 4, 472-477. AJB ISSN 1684-5315 @ 2004 Academic Journals.

Oghenekaro AO, Okhuoya JA, Akpaja EO. 2009 - Growth of Lentinus squarrosulus (M.) Singer on sawdust of different tropical tree species. African Journal of Food Science 3, $007-010$.

Okhuoya AJ, Akpaja EO, Oghenekaro AO. 2005 - Cultivation of Lentinus squarrosulus (Mont.) Singer on sawdust of selected tropical tree species. International Journal of Medicinal Mushrooms 7, 440-441.

Osman ME, Hassa FRH, Khattab OH, Ahmed WA, El-Henawy HE. 2009 - Physiological Stidies on the Growth of Two Different Strains of Lentinus edodes. Australian Journal of Basic and Applied Sciences 3, 4094-4103.

Philippousis A, Zervakis G, Diamantopoulou P. 2001 - Bioconversion of agricultural lignocellulosic wastes through cultivation of the edible mushrooms Agrocybe aegerita, Volvariella volvocea and Pleurotus spp. World J. Microbiol. Biotechnol 17, 191-200.

Prokop S, Albert J. 2008 - Potatoes, Nutrition and diet. FAO's Nutrition and Consumer Protection Division. Retrivedathttp://www. Potato2008.org/en/potato/factsheet.html.

Ramos MJ. 2004 - Biophysiology of Utsuhiratake (Pleurotus pulmunarius) Unpublished Undergraduate Thesis.Central Luzon State University, Science City of Munoz, Nueva Ecija.

Reyes R, Eguchi F, Iijima T, Higaki M. 1997 - Collybia reinakeana, a wild edible mushroom from the forest of Puncan, Nueva Ecija, Philippines. Mushroom Sci Biotechnol 15, 99-102.

Reyes RG, Eguchi F, Iijima T, Higaki M. 1998 - Physiological considerations for efficient colonization of fukorotake Volvariella volvacea. Journal of wood science 44, $408-413$.

Reyes R, Grassel W, Rau R. 2009a - Coconut water as a novel culture medium for the biotechnological production of schizophyllan. J Nature Stud 7, 43-48.

Reyes R, Lopez LLM, Kalaw S, Kumakura K, Kikukawa T, Eguchi F. 2009b - Coprinus comatus, a newly domesticated wild nutraceutical mushroom in the Philippines. J Agric Technol 5, 299-316.

Royse DJ, Bahler BD, Bahler CC. 1990 - Enhanced yield of shitake by saccharine amendment of the synthetic substrate. Appl. Environ. Microbiol 56, 479-482.

Royse DJ. 2003 - Cultivation of Oyster Mushrooms. Pennsylvania State University Press, Pennsylvania.

Rossi IH, Monteiro AC, Machado JO, Andrioli JL, Barbosa JC. 2002 - Shiitake Lentinula edodes production on a sterilized bagasse substrate enriched with rice bran and sugarcane molasses. Brazilian Journal of Microbiology 34, 66 - 71. ISSN 1517-8382.

Smith D, Ryan MJ, Day JG. 2001 - The UK National Culture Collection (UKNCC) Biological Resource: Properties, Maintenance and Management at United Kingdom national culture collection.

Stanley HO, Umolo, EA, Stanley CN. 2011 - Cultivation of oyster mushroom (Pleurotus pulmonarius) on amended corncob substrate Agric. Biol. J. N. Am 2, 1336-1339. 
Sumagawa M, Magae Y. 2005 - Isolation of genes differentially expressed during fruit body development of Pleurotus ostreatus by different display of RAPD. FEMS Microbiology Letters 246, 279-284.

Tinoco R, Pick MA, Duhalt RV. 2001 - Kinetic differences of purified laccases from six Pleurotus ostreatus strains. Lett. Applied Microbiol 32, 331-335.

Valdez AS. 2014 - Optimization of Culture Condition for mycelia growth of Pleurotus djamor. Unpublished Undergraduate Thesis. Central Luzon State University, Science City of Munoz, Nueva Ecija.

Van Aarle IM, Rouhier H, Saito, M. 2002 - Phosphate activities of arbuscular mycorrhizal intraradical and extraradical mycelium, and their relation to phosphorus availability. MycolRes 106, 1224-1229.

Yabo R. 2011 - Biophysiology of Auricularia polytricha. Unpublished Undergraduate Thesis. Central Luzon State University, Science City of Munoz, Nueva Ecija.

Zadrazil F. 1978 - Cultivation of Lentinus. In Biology and Cultivation of Edible Mushroom Chang S.T. and W.A. Hayes eds. New York Academics Press 521-554. 